\title{
The ethical issues of research involving human beings contained in the editorial guidelines of Brazilian medical journals
}

\author{
Os aspectos éticos das pesquisas envolvendo seres humanos contidos nas \\ diretrizes editoriais das revistas médicas brasileiras
}

Guilherme Malafaia', Aline Sueli de Lima Rodrigues², André Talvani ${ }^{3}$

\begin{abstract}
The present study aimed to analyze the ethical aspects contained in the sections "Instructions to authors" of Brazilian medical journals which were highly qualified on the assessment of the Qualis program of Conselho Técnico Científico da Educação Superior (CTC-ES) (Medicine I area - reference year 2007). Moreover, we searched in the journals that present information about the ethical issues involved in research with humans, if these journals inform the authors about how they should confirm to the editors the compliance with ethical issues of their studies. The editorial guidelines of 34 journals (17.6\%, B2 score; $35.3 \%$ B3 score; 47.1\% B4 score) were analyzed. It was observed that only 7 (20.6\%) journals do no mention some ethical questions related to research involving human subjects and that 25 (73.5\%) journals indicate the need for approval of research by Ethics Committee of the institution where the study was conducted. However, less than half (44.1\%) of the journals clearly indicate in their "Instructions to authors" that information about the ethical aspects of research involving human subjects should be cited in the text of the manuscript submitted. Thus, further improvement is still necessary regarding the approach of ethical issues in the editorial guidelines of the Brazilian medical journals analyzed. Researches like this seek to contribute with the discussion about the awareness of editors, so that they mention in the instructions of their journals the principles, rules and ethical standards that must be considered in the research involving human beings.
\end{abstract}

Keywords: Manuscripts, medical; bioethics; editorial policies.

\section{Resumo}

0 presente estudo teve por objetivo analisar os aspectos éticos contidos na seção "Instruções aos autores" dos periódicos médicos brasileiros mais bem conceituados na avaliação do Qualis de Periódicos do Conselho Técnico Científico da Educação Superior (CTC-ES) (Área Medicina I - ano base 2007). Além disso, buscou investigar nos periódicos que disponibilizam alguma informação sobre as questões éticas envolvidas na experimentação em seres humanos, se os mesmos informam aos autores a maneira com que eles devem confirmar aos editores o cumprimento das questões éticas dos seus estudos. As diretrizes editoriais de 34 periódicos (17,6\%, conceito B2; 35,3\% conceito B3; 47,1\% conceito B4) foram analisadas. Foi observado que apenas 7 (20,6\%) dos periódicos analisados não mencionaram alguma questão ética relacionada à pesquisa envolvendo seres humanos e que 25 (73,5\%) deles indicam a necessidade de aprovação da pesquisa pelo Comitê de Ética da instituição onde o estudo foi conduzido. Contudo, menos da metade (44,1\%) dos periódicos analisados deixaram claro em suas "Instruções aos Autores" que informações sobre os aspetos éticos da pesquisa com seres humanos devem ser citados no corpo do manuscrito. Assim, concluiu-se que ainda são necessárias maiores melhorias quanto à abordagem das questões éticas nas diretrizes editoriais dos periódicos médicos brasileiros analisados. Pesquisas como esta visam a contribuir com a discussão sobre a conscientização dos editores para que façam constar nas instruções dos seus periódicos os princípios, normas e padrões éticos que devem ser obedecidos na pesquisa envolvendo seres humanos.

Palavras-chaves: Manuscritos médicos; bioética; políticas editoriais.

Recebido: 20/1/2010

Revisado: 6/7/2010

Aprovado: $12 / 7 / 2010$

Study carried out at Instituto de Educação, Ciência e Tecnologia Goiano, Campus Urutaí, Goiás (GO), Brasil

' Departamento de Ciências Biológicas, Núcleo de Pesquisa em Ciências Ambientais e Biológicas, Instituto Federal Goiano - Campus Urutaí, (GO) Brasil.

2 Instituto de Educação, Ciência e Tecnologia Goiano, Campus Urutaí, Goiás; Doutoranda da Universidade Federal de Ouro Preto (UFOP), Ouro Preto (MG), Brasil

${ }^{3}$ Departamento de Ciências Biológicas \& Programa de Pós-Graduação em Ciências Biológicas, Núcleo de Pesquisa em Ciências Biológicas, Universidade

Federal de Ouro Preto, (MG), Brasil.

Endereço para correspondência: Guilherme Malafaia - Rua JM 13, Quadra 25, Lote 8A, Pires do Rio - GO, Brasil. CEP: $75200-000$ -

E-mail: guilhermebioufop@yahoo.com.br 


\section{Introduction}

According to Cohen ${ }^{1}$, the ethics, as assessment of individual and social behavior, is as old as the history of the Greeks. However, bioethics, understood "as the interdisciplinary examination moral and ethical dimension of human conduct in the field of life sciences and health" has only appeared in the mid- $1970^{2}$, in response to scientific and technological progress, to dissemination of scientific research involving human use, to strengthening of social movements in the 1960s and the emergence of new awareness of the individual and social rights ${ }^{3}$.

According to Filho ${ }^{4}$, the term "bioethics" is a neologism that was used for the first time by Van Rensselaer Potter, a biochemist involved in the research of cancer at the University of Wisconsin (USA). According to the author, it would be necessary to develop a new field of ethics that could be directed to protect human subjects, their survival and to improve life quality. However, even according to Filho ${ }^{4}$, it was André Hellegers, a Dutch obstetrician who worked at Georgetown University (USA), who transposed the term "bioethics" for medical and biological sciences. Consequently, a practical application for this new field of theoretical knowledge was created, consolidated with the publication of the book "Principles of biomedical ethics", in 1979, by Tom Beauchamp and James Childress. This book refers to the work that, for the first time, presented a theoretical model in bioethics aiming to explore the moral dilemmas in medical and biological field. The proposal of these authors, following the principles chosen by the Belmont Report (respect of people, beneficence and justice) to guide the research involving human subjects, is deployed in four prima facie principles, which are: i) autonomy (right of individuals to act according to their will), ii) charities (with respect to doing good), iii) nonmaleficence (obligation not to cause harm) and iv) justice (understood as distributive justice).

After the publication of this book, advances in the field of bioethics have taken place over the years and important discussions have been conducted regarding the ethical standards in the conduct of research involving human subjects having the publication of these studies ${ }^{5,6}$. In the context of scientific publications, the Resolution 196/96 of the Conselho Nacional de Saúde, which governs the ethical conduct of research in Brazil, although not stipulating specific rules, establishes that the results of research in human subjects should be published, whether favorable or not, fact that presents important implications in the process of publishing scientific journals. The prestige of any journal is related to rigid editorial policies, publishing articles that have followed scientific and ethical rules and with potential to influence the scientific development of the research area to which it belongs ${ }^{8}$.

However, how have the Brazilian medical journals addressed this question in their editorial policies? More than ten years after the publication of Resolution CNS 196/96, are its theoretical assumptions reflected in the ethical guidelines of the journals responsible for national dissemination of scientific knowledge? As pointed out by Rowan-Legg et al. ${ }^{9}$, the adherence to ethical standards in the editorial policies of journals, which publish work involving research with human subjects is important, since the scientific community could follow more closely those ethical assumptions, if explicit in its guidelines to authors the rejection of manuscripts that do not follow these assumptions. In addition, more stringent rules for publication generate greater confidence of readers and encourage publishing high quality scientific studies. In Brazil, there is emphasis on the study of Sardenberg et al. ${ }^{10}$, in which the objective was to evaluate the recommendations related to the ethics of investigation in human subjects in instructions to authors of Brazilian scientific journals. The authors identified a serious gap in the instructions to authors of the journals investigated related to absence of requirements for compliance of ethical standards established in various important documents on the ethical aspects of research, including the CNS Resolution 196/96.

Thus, considering the importance of the topic investigated and the relevance of the "Instructions to authors" in the evaluation of editorial policy of journals ${ }^{11}$, the objective of this study is to examine the ethical aspects contained in that section of 34 Brazilian medical journals listed in assessment of the Qualis program (Medicine I area) of Conselho Técnico Científico da Educação Superior (CTC-ES) (reference year of 2007). As discussed by Dimitri and Christakis ${ }^{12}$, although the ethics of research conduct receive considerable attention, much less attention has been given to the ethics of the publication process. Thus, it is therefore essential to verify whether the Brazilian medical journals have shown in their "Instructions to authors" clear requirements on compliance with ethical standards contained in various documents relating to experiments with human subjects.

\section{Methods}

The ethical aspects of the guidelines contained in "Instructions to authors" on research involving human subjects were assessed based on the methodology used in the studies of Amdur and Biddle ${ }^{13}$, Sardenberg et al. ${ }^{10}$ and, more recently, in the work of Rowan-Legg et al..

\section{Selection of sample}

This study investigated the content of the guidelines of "Instructions to authors" of Brazilian medical journals, selected according to the following inclusion criteria:

- journals listed in assessment of Qualis program of CTC-ES (Medicine I area) which received one of six major concepts concerning the reference year 2007 (A1, A2, B1, B2, B3 and B4)*;

- journals that publish not only review papers, but also original articles on various areas of medicine;

\footnotetext{
* As decided by CEC-ES (http://www.capes.gov.br/avaliacao/qualis), the classification of Brazilian journals was modified and is currently divided into concepts indicative of their quality. These are: A1, the highest, A2, B1, B2, B3, B4, B5 and C - with zero weight.
} 
- journals that publish manuscripts of research involving human subjects;

- journals of major impact on national medicine.

\section{Assessment of ethical aspects related to research involving human subjects con- tained in the "Instructions to authors"}

The instructions to authors of each journal were reviewed to determine the presence of specific guidelines regarding the ethical standards for reporting studies involving human subjects. Each journal's most detailed instruction list was reviewed and assigned to one of the following categories: Category 1: journals that refer to the need for approval of research by Ethics Committee of the institution where the study was conducted; Category 2: journals that require that the manuscript submitted follows the ethical standards' contained in Declarations, Resolutions or Codes of Ethics (national and/or international) about the research involving human subjects; Category 3: journals that present excerpts from some of documents mentioned governing research involving human subjects, Category 4: journals that explain the need of informed consent of patient involved in the research; Category 5: journals that mention, direct or indirect, the guidelines of "Uniform Requirements for Manuscripts Submitted to Biomedical Journals" (of International Committee of Medical Journal Editors' - ICMJE) and Category 6: journals that do not mention the ethical standards' related to research involving human subjects. It is important to emphasize that the same journal may have been included in more than one category, except for Category 6.

In addition, the journals were assessed with respect to the availability of information to authors about how they should confirm to editors the compliance with ethical standards in the manuscripts submitted. In order to do this, the categories shown in Table 1 were estab-

Table 1 - Categories established for the evaluation of journals regarding information provided to authors about how they should confirm to editors the compliance of ethical standards in the manuscripts submitted

\begin{tabular}{ll}
\hline Categories & Description of categories \\
\hline A & $\begin{array}{l}\text { Clearly indicates that information about the ethical aspects } \\
\text { of research involving human subjects should be cited in the } \\
\text { text of paper }\end{array}$ \\
B & $\begin{array}{l}\text { Requires letter or document signed by authors stating com- } \\
\text { pliance of ethical aspects involved in research with human } \\
\text { subjects }\end{array}$ \\
C & $\begin{array}{l}\text { Requests copy of the document referring to the informed } \\
\text { consent of subjects involved in research }\end{array}$ \\
D & $\begin{array}{l}\text { Requires copy of the authorization of Ethics Commission/ } \\
\text { Committee which approved the study }\end{array}$ \\
E & $\begin{array}{l}\text { It is understood that the study was conducted within the } \\
\text { rules, standards or principles, without the requirement of any } \\
\text { certifying document }\end{array}$ \\
F & $\begin{array}{l}\text { Does not contain information about how the authors of } \\
\text { manuscripts submitted should confirm to editors the compli- } \\
\text { ance with ethical aspects of study }\end{array}$ \\
\hline
\end{tabular}

lished. The information about the journals were obtained from the site of the journal during the months of June and July of 2009.

To minimize the subjectivity of this type of study (observational), the editorial guidelines of journals were analyzed separately by two authors. Only after agreement between reviewers the data were computed.

\section{Results and discussion}

This study analyzed 34 Brazilian medical journals, out of which $6(17.6 \%)$ achieved B2 score, 12 (35.3\%) B3 score and 16 (47.1\%) B4 score. No Brazilian journal, listed in the Qualis program (CTC-ES) (Medicine I area), obtained A1, A2 and B1 scores in the reference year 2007 (Table II).

Regarding the citation of need for approval of research by Ethics Committee of institution where the study was conducted (Category 1), it was observed that $25(73.5 \%)$ journals indicate this need in their "Instructions to authors". Moreover, only 13 (38.2\%) journals require that authors follow the ethical guidelines contained in declarations, resolutions or codes of ethics (international and/or national) related to research involving human subjects (Category 2).

Since the publication of the Code of Nuremberg ${ }^{14}$, which was revised, resulting in the Declaration of Helsinki ${ }^{15}$, many important documents state that the experimental procedures involving humans must be submitted to review and approval of an ethics committee before the resulting work is submitted for publication. The Declaration of Helsinki, which according to Zoboli and Spinetta ${ }^{16}$ has brought great advances in the area of ethics in research with human subjects, emphasizes that "reports of experimentation not in accordance with the principles stated in this Declaration should not be accepted for publication". Among the documents cited by journals investigated, the Declaration of Helsinki (mentioned eight times), Resolution CNS 196/96 (mentioned five times), Consolidated Standards of Reporting Trials (CONSORT) and the Committee on Publication Ethics (COPE) (the last two mentioned only once) are highlighted (Table III).

Among the journals that mentioned some of these documents, less than half (46.1\%) provide guidance about how to access these documents (in Portuguese or English for the international documents). As example, the contents of instructions to authors of Acta Cirúrgica Brasileira may be cited, which refers to the Declaration of Helsinki, Resolution CNS 196/96, CONSORT and International Clinical Trials Registry Platform (ICTRP), informing the links that allow access to these documents.

Resolution CNS 196/96, as said before, establishes the Guidelines and Standards for Research involving human subjects to be followed in Brazil. As discussed by Tenório et al. ${ }^{17}$, this resolution is considered a regulatory framework in Brazilian scientific research involving individuals, having its construction derived from analysis of international declarations and guidelines about the research with human subjects, whose central objective is to ensure the respect for life? 
Table 2 - Brazilian medical journal selected for analyses*

\begin{tabular}{|c|c|c|c|c|c|c|}
\hline Journals & Issn & Periodicity & $\begin{array}{l}\text { Qualis (2007) } \\
\text { medicine i area }\end{array}$ & $\begin{array}{l}\text { The journal is } \\
\text { indexing service? }\end{array}$ & Publisher & $\begin{array}{l}\text { Year of } \\
\text { creation }\end{array}$ \\
\hline $\begin{array}{l}\text { 1. Anais da Academia Brasileira de } \\
\text { Ciências }\end{array}$ & $0001-3765$ (р.v.) e $1678-2690$ (o.v.) & Quarterly & B2 & Yes & Academia Brasileira de Ciências & 1929 \\
\hline 2. Arquivos de Neuro-Psiquiatria & 0004-282X (p.v.) e 1678-4227 (o.v.) & Quarterly & B2 & Yes & $\begin{array}{l}\text { Associação Arquivos de Neuro- } \\
\text { Psiquiatria Dr. Oswaldo Lange }\end{array}$ & 1970 \\
\hline $\begin{array}{l}\text { 3. Brazilian Journal of Medical and } \\
\text { Biological Research }\end{array}$ & 0100-879X (p.v.) e $1678-4510$ (o.v.) & Monthly & B2 & Yes & $\begin{array}{c}\text { Associação Brasileira de Divulgação } \\
\text { Científica }\end{array}$ & 1981 \\
\hline $\begin{array}{l}\text { 4. International Brazilian Journal } \\
\text { of Urology }\end{array}$ & 1677-5538 (p.v.) e $1677-6119$ (o.v.) & Bimonthly & B2 & Yes & Sociedade Brasileira de Urologia & 2000 \\
\hline $\begin{array}{l}\text { 5. Revista Brasileira de Psiquiatria } \\
\text { (São Paulo) }\end{array}$ & $1516-4446$ (p.v.) e 1809-452X (o.v.) & Quarterly & B2 & Yes & Associação Brasileira de Psiquiatria & $\mathrm{x}$ \\
\hline $\begin{array}{l}\text { 6. Revista de Saúde Pública (versão } \\
\text { impressa) }\end{array}$ & 0034-8910 (p.v.) e 1518-8787 (o.v.) & Bimonthly & B2 & Yes & $\begin{array}{l}\text { Faculdade de Saúde Pública da } \\
\text { Universidade de São Paulo }\end{array}$ & 1967 \\
\hline 7. Acta Cirúrgica Brasileira & $0102-8650$ (р.v.) e 1678-2674 (o.v.) & Bimonthly & B3 & Yes & $\begin{array}{l}\text { Sociedade Brasileira para o Desen- } \\
\text { volvimento da Pesquisa em Cirurgia }\end{array}$ & 1986 \\
\hline $\begin{array}{l}\text { 8. Arquivos Brasileiros de Endo- } \\
\text { crinologia \& Metabologia }\end{array}$ & $0004-2730$ (р.v.) e 1677-9487 (o.v.) & 9 issues/year & B3 & Yes & $\begin{array}{c}\text { Sociedade Brasileira de Endocrinolo- } \\
\text { gia e Metabologia }\end{array}$ & $\mathrm{x}$ \\
\hline $\begin{array}{l}\text { 9. Cadernos de Saúde Pública } \\
\text { (Fiocruz) }\end{array}$ & $0004-2730$ (p.v.) e $1677-9487$ (o.v.) & Monthly & B3 & Yes & Escola Nacional de Saúde Pública & 1985 \\
\hline $\begin{array}{l}\text { 10. Jornal Brasileiro de Pneumo- } \\
\text { logia }\end{array}$ & $1806-3713$ (p.v.) e 1806-3756 (o.v.) & Monthly & B3 & Yes & $\begin{array}{c}\text { Sociedade Brasileira de Pneumologia } \\
\text { e Tisiologia }\end{array}$ & 1975 \\
\hline $\begin{array}{l}\text { 11. Jornal de Pediatria (Rio de } \\
\text { Janeiro) }\end{array}$ & $0021-7557$ (p.v.) e 1678-4782 (o.v.) & Bimonthly & B3 & Yes & Sociedade Brasileira de Pediatria & 1934 \\
\hline $\begin{array}{l}\text { 12. Memórias do Instituto Oswaldo } \\
\text { Cruz }\end{array}$ & 0074-0276 (p.v.) e 1678-8060 (o.v.) & 9 issues/year & B3 & Yes & Fundação Oswaldo Cruz & 1909 \\
\hline $\begin{array}{l}\text { 13. Revista Brasileira de Otor- } \\
\text { rinolaringologia }\end{array}$ & $0034-7299$ (p.v.) e 1806-9312 (o.v.) & Bimonthly & B3 & Yes & $\begin{array}{l}\text { Associação Brasileira de Otor- } \\
\text { rinolaringologia e Cirurgia Cérvico- } \\
\text { Facial }\end{array}$ & 1933 \\
\hline $\begin{array}{l}\text { 14. Revista da Associação Médica } \\
\text { Brasileira }\end{array}$ & $0104-4230$ (p.v.) e 1806-9282 (o.v.) & Bimonthly & B3 & Yes & Associação Médica Brasileira & $\mathrm{x}$ \\
\hline $\begin{array}{l}\text { 15. Revista do Instituto de Medicina } \\
\text { Tropical de São Paulo }\end{array}$ & $0036-4665$ (p.v.) e 1678-9946 (o.v.) & Bimonthly & B3 & Yes & $\begin{array}{l}\text { Instituto de Medicina Tropical de } \\
\text { São Paulo }\end{array}$ & 1959 \\
\hline 16. São Paulo Medical Journal & $1516-3180$ (p.v.) e $1806-9460$ (o.v.) & Bimonthly & B3 & Yes & Associação Paulista de Medicina & 1932 \\
\hline $\begin{array}{l}\text { 17. The Brazilian Journal of Infec- } \\
\text { tious Diseases }\end{array}$ & $1413-8670$ (p.v.) e $1678-4391$ (o.v.) & Bimonthly & B3 & Yes & $\begin{array}{l}\text { Sociedade Brasileira de Doenças } \\
\text { Infecciosas }\end{array}$ & 1997 \\
\hline 18. Clinics & 1807-5932 (p.v.) e 1980-5322 (o.v.) & Bimonthly & B4 & Yes & $\begin{array}{l}\text { Faculdade de Medicina da Universi- } \\
\text { dade de São Paulo }\end{array}$ & 2001 \\
\hline $\begin{array}{l}\text { 19. Revista Brasileira de Cirurgia } \\
\text { Cardiovascular }\end{array}$ & $0102-7638$ (р.v.) e $1678-9741$ (o.v.) & Quarterly & B4 & Yes & $\begin{array}{c}\text { Sociedade Brasileira de Cirurgia } \\
\text { Cardiovascular }\end{array}$ & $\mathrm{x}$ \\
\hline 20. Ciência \& Saúde Coletiva & 1413-8123 (p.v.) e 1678-4561 (o.v.) & Bimonthly & B4 & Yes & $\begin{array}{l}\text { Associação Brasileira de Pós- } \\
\text { Graduação em Saúde Coletiva }\end{array}$ & $\mathrm{x}$ \\
\hline $\begin{array}{l}\text { 21. Jornal Brasileiro de Patologia e } \\
\text { Medicina Laboratorial }\end{array}$ & $1676-2444$ (p.v.) e $1678-4774$ (o.v.) & Bimonthly & B4 & Yes & $\begin{array}{l}\text { Sociedade Brasileira de Patologia } \\
\text { Clínica/Medicina Laboratorial }\end{array}$ & $\mathrm{x}$ \\
\hline 22. Jornal Brasileiro de Psiquiatria & 0047-2085 (p.v.) e 1982-0208 (o.v.) & Quarterly & B4 & Yes & $\begin{array}{l}\text { Instituto de Psiquiatria da Universi- } \\
\text { dade Federal do Rio de Janeiro }\end{array}$ & $\mathrm{x}$ \\
\hline 23. Jornal de Pneumologia & 0102-3586 (p.v.) e 1678-4642 (o.v.) & Bimonthly & B4 & Yes & $\begin{array}{c}\text { Sociedade Brasileira de Pneumologia } \\
\text { e Tisiologia }\end{array}$ & $\mathrm{x}$ \\
\hline $\begin{array}{l}\text { 24. Journal of Epilepsy and Clinical } \\
\text { Neurophysiology }\end{array}$ & 1676-2649 (p.v.) e 1980-5365 (o.v.) & Quarterly & B4 & Yes & Liga Brasileira de Epilepsia & $\mathrm{x}$ \\
\hline 25. Physis - Revista de Saúde Coletiva & 0103-7331 (p.v.) e $1809-4481$ (o.v.) & Quarterly & B4 & Yes & Instituto de Medicina Social & $\mathrm{x}$ \\
\hline $\begin{array}{l}\text { 26. Revista Brasileira de Aneste- } \\
\text { siologia }\end{array}$ & $0034-7094$ (p.v.) e 1806-907X (o.v.) & Bimonthly & B4 & Yes & $\begin{array}{l}\text { Sociedade Brasileira de Aneste- } \\
\text { siologia }\end{array}$ & 1951 \\
\hline $\begin{array}{l}\text { 27. Revista Brasileira de Educação } \\
\text { Médica }\end{array}$ & 0100-5502 (p.v.) e 1981-5271 (o.v.) & Quarterly & B4 & Yes & $\begin{array}{c}\text { Associação Brasileira de Educação } \\
\text { Médica }\end{array}$ & $\mathrm{x}$ \\
\hline $\begin{array}{l}\text { 28. Revista Brasileira de Ginecolo- } \\
\text { gia e Obstetrícia }\end{array}$ & 0100-7203 (p.v.) e 1806-9339 (o.v.) & Monthly & B4 & Yes & $\begin{array}{l}\text { Federação das Sociedades de } \\
\text { Ginecologia e Obstetrícia }\end{array}$ & $\mathrm{x}$ \\
\hline $\begin{array}{l}\text { 29. Revista Brasileira de Hematolo- } \\
\text { gia e Hemoterapia }\end{array}$ & $1516-8484$ (p.v.) e $1806-0870$ (o.v.) & Bimonthly & B4 & Yes & $\begin{array}{l}\text { Associação Brasileira de Hematolo- } \\
\text { gia e Hemoterapia }\end{array}$ & $\mathrm{x}$ \\
\hline $\begin{array}{l}\text { 30. Revista Brasileira de Medicina } \\
\text { do Esporte }\end{array}$ & 1517-8692 (p.v.) e $1806-9940$ (o.v.) & Bimonthly & B4 & Yes & $\begin{array}{l}\text { Sociedade Brasileira de Medicina } \\
\text { do Esporte }\end{array}$ & 1995 \\
\hline $\begin{array}{l}\text { 31. Revista Brasileira de Terapia } \\
\text { Comportamental e Cognitiva }\end{array}$ & $1517-5545$ (p.v.) e 1982-3541 (o.v.) & Biannual & B4 & Yes & $\begin{array}{l}\text { Associação Brasileira de Psicoterapia } \\
\text { e Medicina Comportamental }\end{array}$ & $\mathrm{x}$ \\
\hline 32. Revista de Psiquiatria Clínica & 0101-6083 (p.v.) e 1806-938X (o.v.) & Quarterly & B4 & Yes & $\begin{array}{l}\text { Departamento e Instituto de Psiq- } \\
\text { uiatria da Faculdade de Medicina da } \\
\text { Universidade de São Paulo }\end{array}$ & 1972 \\
\hline $\begin{array}{l}\text { 33. Revista de Psiquiatria do Rio } \\
\text { Grande do Sul }\end{array}$ & 0101-8108 (p.v.) e 1806-9398 (o.v.) & Quarterly & B4 & Yes & $\begin{array}{l}\text { Sociedade de Psiquiatria do Rio } \\
\text { Grande do Sul }\end{array}$ & 1979 \\
\hline 34. Revista do Colégio de Cirurgiões & 0100-6991 (p.v.) e 1809-4546 (o.v.) & Bimonthly & B4 & Yes & Colégio Brasileiro de Cirurgiões & 1929 \\
\hline
\end{tabular}

"All information contained in this table where removed from the site of the journal during the months of June and July of 2009. p.v.: printed version; o.v. online version; $x$ : data not available. 
Table 3 - Documents about the ethical questions mentioned in the "Instructions to authors" of journals investigated

\begin{tabular}{lc}
\hline Mentioned documents & $\begin{array}{c}\text { Number of times } \\
\text { mentioned }^{*}\end{array}$ \\
\hline Declaration of Helsinki & 8 \\
Resolution CNS 196/96 & 5 \\
Consolidated Standards of Reporting Trials (CONSORT) & 1 \\
Committee on Publication Ethics (COPE) & 1 \\
International Clinical Trials Registry Platform (ICTRP) & 1 \\
\hline
\end{tabular}

*The sum of number of times the documents were cited exceeds the number of journals that mention documents (Category 2 ) because some journals cited more than one document in the "Instructions to authors" session.

The Resolution incorporates several concepts of bioethics and has the informed consent of individual and the need for prior approval by ethics committee (established in Resolution CNS 01/1988, which was repealed by Resolution CNS 196/96), and groups the four basic frameworks of bioethics: independent, non-maleficence, beneficence and justice. This resolution also ensures the rights and duties that relate to scientific community, the subjects of research and the state. It is important to emphasize that the need for approval by Ethics Committee for research involving human subjects is mentioned in several national resolutions. These documents complement the Resolution CNS 196/96, such as the Resolution CNS 251/97, Resolution CNS 292/99, Resolution CNS 303/00, Resolution 340/04 and Resolution 347/05.

In relation to Category 3, it was observed that only one journal (2.9\%) mentions in its "Instructions to authors" excerpts of documents dealing with ethical questions in research involving humans. The Revista Brasileira de Anestesiologia, to emphasize that the Medical Ethics Code of the Federal Medicine Council establishes strict rules concerning for work of scientific research, writes down the articles 122 to 130 ruling what is forbidden in scientific research. Certainly, this type of information contributes to improve the quality and seriousness of the work to be published, and encourages compliance with the ethical aspects established in various national and international documents about human experimentation.

In relation to Category 4 , only $6(17.6 \%)$ journals explain the need for informed consent signed by the patients involved in the research. These results are worrying, because since the creation of Nuremberg Code, in $1947^{14}$, informed consent from volunteers undergoing research is needed. In addition, other important documents which contain chapters related to medical research and scientific work, such as the Brazilian Code of Medical Ethics, the Uniform Requirements for Manuscripts Submitted to Biomedical Journals, the Guide to Biomedical and Epidemiological Research Council for the International Organizations of Medical Sciences/World Health Organization (CIOMS / WHO), and the Resolution CNS 196/96 refer to the importance of obtaining the free and informed consent of individuals or groups that participate in a research. Thus, a failure is observed in the editorial policy of journals analyzed concerning the absence of explicit information that research involving human subjects must obtain the free and informed consent of patients before carrying out the work and submitting the study to journal.

Another interesting aspect observed in this study is related to Category 5. In no section "Instructions to authors" of the journals analyzed was identified any direct or indirect mention to the ethical guidelines of Uniform Requirements for Manuscripts Submitted to Biomedical Journals, document proposed by the International Committee of Medical Journal Editors (ICMJE), whose most recent revision was in October $2008^{18}$. This document, while making recommendations regarding the technical aspects of preparation of manuscripts, also emphasizes its recommendations about ethical aspects related to research involving human subjects. In the item II.F "Protection of $\mathrm{Hu}$ man Subjects and Animals in Research", the document recommended that when reporting experiments on human subjects, authors should indicate whether the procedures followed were in accordance with the ethical standards of the responsible committee on human experimentation (institutional and national) and with the Helsinki Declaration of 1975 , as revised in 2000 .

In relation to Category 6, it was observed that only 7 (20.6\%) journals do no mention ethical questions related to research involving human subjects. These results, associated with the one previously presented, when compared to the work of Sardenberg et al. ${ }^{10}$, show an improvement on the ethical approach available in the "Instructions to authors" of national medical journals. However, it was found that many journals still have gaps in their guidelines for they do not mention, for example, the need for approval of research developed by Ethics Committee and/or documents (national or international) governing the research with human subjects. In the study of Sardenberg et al. ${ }^{10}$ the authors observed that in $110(79.1 \%)$ of the 139 journals analyzed, no recommendations related to ethics were found; 17 (12.2\%) required previous approval by the institutional committee; $3(2.1 \%)$ the procedures should be in accordance with the Declaration of Helsinki; 1 $(0.7 \%)$ recommends the obtainment of informed consent; 5 (3.5\%) recommend the use of Uniform Requirements for Manuscripts Submitted to Biomedical Journals and 3 (2.1\%) follow no specified rules.

In another study, Sardenberg et al. ${ }^{19}$ analyzes the norms about ethics in research with human subjects included in the guidelines of orthopedics and trauma scientific journals, also found failures in the editorial policy of journals related to lack of information about the ethical questions involved in research with human subjects. Thirty-eight journals were analyzed: $52.6 \%$ do not mention ethical aspects; $28.9 \%$ submit to approval by the Institution's Ethical Committee; 15.7\% follow the orientation of the Uniform Requirements for Manuscripts Submitted to Biomedical Journals and 2.6\% ask the patients' consent. Aspects related to the patients' privacy were found in $36.8 \%$ of the studied journals.

Pellizzom et al. ${ }^{8}$ analyzed 20 Brazilian scientific journals that publish manuscripts related to the surgical area (listed in the ranking of these journals in the Medicine III area of the Qualis program, reference year of 2006), found among other results, that the compliance with ethical re- 
search principles was mentioned in the "Instructions to authors" of 18 (90\%) journals, demonstrating the concern of editors of investigated journals about the ethical questions involved in research with human subjects.

Internationally, studies have demonstrated the concern of the scientific community about the requirements of the journals to fulfill the ethical guidelines to authors of medical manuscripts. Several studies have been devoted to research, for over a decade, the ethical approach of international journals explicit in theirs "Instructions to authors", as seen in studies of Olson and Jobe ${ }^{20}$, Amdur and Biddle $^{13}$, Rennie and Yank $^{21}$, Matot et al..$^{22}$, Yank and Rennie ${ }^{23}$, Weil et al. ${ }^{24}$, Atlas ${ }^{25}$ e Myles and $\operatorname{Tan}^{26}$. Recently Rowan-Legg et al. ${ }^{9}$, compare the current guidelines given to authors by journal editors regarding institutional review board approval and disclosure of conflict of interest with those published 10 years earlier. The study focused on the 103 remaining journals from the 2005 version of the Abridged Index Medicus. Hard-copy journal instructions were reviewed for 1995 , while online instructions were used for the 2005 data collection. According to authors, the "Instructions to authors" regarding ethical standards have improved; however, the ethical guidelines presented to authors need further clarification and standardization.

This study also investigated in journals that provide some information about the ethical questions involved in experimentation on human subjects, if the periodical reports to authors how they must confirm to editors the ethics aspects of their studies.

Less than half (44.1\%) of the journals clearly indicate in their "Instructions to authors" that information about the ethical aspects of research involving human subjects should be cited in the text of manuscript submitted (Category A) (Table IV). All journals that mention this information require its inclusion in the section that describes the methodology used in the study, as in "Instructions to authors" of Revista Brasileira de Otorrinolaringologia ("In Material and Methods one shall find a detailed description of the sample and the tools used in the investigation. In studies involving human beings or animals, the protocol number of approval of the study by a Research Ethics Council") and in the Arquivos de Neuro-Psiquiatria ("method: subjects and procedures, explicit reference regarding compliance with the applicable ethical standards, including the name of the Ethics Commission which approved the study and the agreement of patients or their relatives").

In relation to Category B, only $14.7 \%$ of the journals require a letter confirming compliance with the ethical aspects involved in research with humans (Table IV). As to the request of sending the copy of the document, obtaining the informed consent of subjects involved in research (Category C), a low number of journals also make explicit this requirement in their "Instructions to authors". Only $8.8 \%$ of the analyzed journals provide such information (Table IV).

Furthermore, 23.5\% explain in their "Instructions to authors" the requirement of sending the copy of authorization of the Ethics Commission/Committee which approved the study (Category D).
Moreover, in $11.7 \%$ of the journals, it is understood that the study was conducted within the rules, standards or principles, without the requirement of any certifying document (Category E). Regarding the lack of information about how the authors should confirm to editors the compliance with the ethical aspects of their studies (Category F), $23.5 \%$ of journals have been framed in this category (Table IV).

These results, when compared with data from Sardenberg et al. ${ }^{10}$, also show an improvement related to the provision of information about how the authors should confirm to editors the compliance with the ethical aspects of their studies, despite the finding that a considerable percentage of journals still has failures. Sandernberg et al. ${ }^{10}$ found that in 29 of the 139 reviewed journals that have references to ethics, the requirements are applied as follows: 15 (51.7\%) the information must be included in the text; in $2(6.8 \%)$ the authors must send a letter informing how the ethics standards were followed; in 1 (3.4\%) a copy of the approval by the institutional committee must be included; in 1 (3.4\%) believed the authors followed the standards and in 10 (34.4\%) no specific reference was made.

Generally, one can assume that one of the reasons to explain the improvement in the ethical approach identified in the guidelines to authors of medical journals reviewed (when compared to approach found in Sandernberg et al. ${ }^{10}$ ) refers to advances in the field of bioethics that have been made over the years. Cohen et al. ${ }^{1}$, using a bibliographic analysis, conducted between 1974 and 2004, observed that more than 100 thousand works about ethics or bioethics were published in journals indexed by Medline database, not counting the books or discussions about the subject. Further evidence of the importance of bioethics can be noted in the promulgation of the Universal Declaration on Bioethics and Human Rights. In October 2005, the General Conference of UNESCO adopted by acclamation the Universal Declaration on Bioethics and Human Rights. For the first time in the history of bioethics, Member States committed themselves and the international community to respect and apply the fundamental principles of bioethics set forth within a single text. This Declaration certainly helped the dissemination of ethical questions related to research involving human subjects.

However, despite advances in scientific publications, which reflect the evolution of "bioethical thought" of researchers and the dissemina-

Table IV - Frequency of journals that mention how the authors should confirm to editors the compliance with the ethical aspects of submitted manuscripts

\begin{tabular}{lc}
\hline Categories & Frequence $(\%)^{*}$ \\
\hline A & 44.1 \\
B & 14.7 \\
C & 8.8 \\
D & 23.5 \\
E & 11.7 \\
F & 23.5 \\
\hline
\end{tabular}

*The sum of frequencies of journals exceeds the total percentage because some were classified in more than one category of evaluation. 
tion of ethical principles in medical research, even greater improvements are needed on the approach to ethical aspects in the editorial guidelines of the Brazilian medical journals. These improvements relate to those concerning the dissemination of information about the requirement of strict observance of ethical assumptions by researchers who submit their manuscripts for publication. Whereas the concept "publish or perish", the worldwide scientific community is seen pressed to publish their scientific production, ethical questions, guidelines about the research and strict norms for publication are required as important safeguards that should be considered. For Spinetta ${ }^{27}$, there is still no conclusive evidence about how and to what extent people can be safely exposed to different research protocols. In addition, we cannot guarantee that the benefits of any research are always greater than the risks to physical integrity, mental and social subjects.

It is important to emphasize that this study was limited to assess the contents of "Instructions to authors" of selected journals, because many times this section is the first and only means of communication between researchers and editors. Therefore, it was not made with the editors or analysis of the manuscripts published in their journals. Thus, it is considered that the results presented in this study refer to a partial analysis of the editorial policy of journals about ethical aspects related to research with human subjects. In addition, this study focused on published journal guidelines and may not reflect actual editorial practice; it may fail to reveal more flexible interpretation of the rules or the application of non-published standards on the part of journal editors. Anyway, it is important that studies like this be developed, relating to the dissemination of scientific knowledge regarding the principles of ethics ${ }^{28}$ adopted in the editorial policies of scientific journals.

Recently, Brazil was highlighted in two important international researches related to scientific research and its publications. It reinforces the need to enhance the ethical aspects available in our journals. The first refers to the publication of Department of Health and Human Services of the Government of USA on a survey conducted in 84 countries, identifying approximately 900 laws and resolutions about the protection of human subjects in research projects ${ }^{29}$. In this compilation, Brazil stood out among Latin American countries due to three key institutions (the Conselho Nacional de Saúde - CNS, Comissão Nacional de Ética em Pesquisa - CONEP and Comissão Técnica Nacional de Biossegurança-CTNBio), three decrees and ten resolutions regulating both the general aspects of research in humans, as specific aspects of research with new drugs, biological, genetic, indigenous people, etc. The second study refers to the rise of Brazil in the ranking of countries that most published scientific articles in 2008. Considered the best placed country in South America, Brazil now occupies the 13th position of statistics carried out by Thomson Reuters that reports annually the numbers of scientific papers published in 200 countries $^{30}$.

According to Guimarães ${ }^{31}$, the comparison to higher-performance countries gave a clearer grasp of Brazil's health research challenge in order to increase the citation indices and better qualify such research. Thus, as emphasized by Sandernberg et al. ${ }^{10}$, the editorial policy of Brazilian scientific journals can improve not only the technical aspects of manuscripts for publication, but also the ethics of studies conducted in the country, contributing effectively to the general improvement in national publications in different areas of medical sciences.

We conclude that, despite advances found in ethical approach contained in the "Instructions to authors", many aspects still need to be improved. These improvements aim to standardize the main ethical guidelines related to research involving human subjects available in national journals, regardless of its concept in the Qualis program. Such improvements can not only provide better quality in published manuscripts and encourage compliance of the ethical standards contained in various national documents governing human experimentation, but also can increase the transparency of editorial policies adopted by medical journals.

We would like to finish this study reinforcing some recommendations based on the recent work by Rowan-Legg et al. ${ }^{9}$ and suggesting others:

I) the journals that have not required or do not emphasize the need for approval of study by Ethics Committee must urgently adjust their editorial guidelines to the fulfillment of these issues before the publication of studies involving human experimentation;

II) the journals should make clear in their guidelines the need for dissemination of ethical information involved in the studies in the section "Material and Methods" or "Methodology" of manuscripts;

III) the journals must disclose and provide information about the access to national and international documents that regulate the research with human subjects;

IV) the journals should include in their guidelines for evaluation of manuscripts a specific topic for the verification of essential requirements relating to research with human subjects in order to ensure better monitoring of fulfillment of the established ethical standards.

This research aims to contribute to the discussion on the awareness of editors to make the instructions appear in their journals: principles, rules and ethical standards to be followed in research involving humans.

\section{Conflicts of interest}

None.

\section{Referências}

1. Cohen C. Por que pensar a bioética? Rev Assoc Med Bras. 2008;54(6):471-86
2. Post SG. Introduction. In: Post SG. Encyclopedia of Bioethics. 3rd. ed. New York: Prentice Hall; 2004; p. xi-v. 
3. Neves MCP. Comissões de ética: das bases teóricas a actividade quotidiana. Coimbra: Gráfica Coimbra; 2002.

4. Filho JMarques. Ética em Pesquisa: dez anos da resolução CNS 196/96. Rev Bras Reumatol. 2007;47(1):2-3.

5. Albert DM, Liesegang TJ, Schachat AP. Meeting our ethical obligations in medical publishing: responsibilities of editors, authors, and readers of peerreviewed journals. Arch Ophthalmol. 2005;123(5):684-6.

6. Fontanarosa PB, Flanagin A, DeAngelis CD. Reporting conflicts of interest, financial aspects of research, and role of sponsors in funded studies. JAMA. 2005;294(1):110-1.

7. Brasil. Ministério da Saúde/Conselho Nacional de Saúde. Resolução 196/96. Diretrizes e Normas Regulamentadoras de Pesquisa envolvendo Seres Humanos. Brasília: Ministério da Saúde; 1996.

8. Pellizzon RF, Montero EFS, Población DA, Monteiro E, Castro RCF. Brazilian scientific journals in surgery. III: analysis of the Instructions for authors based on Vancouver uniform requirements. Acta Cir Bras. 2007;22(6):511-8

9. Rowan-Legg A, Weijer C, Gao J, Fernandez C. A comparison of journal instructions regarding institutional review board approval and conflict-of-interest disclosure between 1995 and 2005. J Med Ethics. 2009;35(1):74-8.

10. Sardenberg T, Müller SS, Pereira HR, De Oliveira RA, Hossne WS. Análise dos aspectos éticos da pesquisa em seres humanos contidos nas Instruções aos Autores de 139 revistas científicas brasileiras. Rev Ass Med Bras. 1999;45(4):295-302.

11. Goldenberg S, Población DA, Gomes PO, Soares AL, Ferreira JR, Kafejian AP, et al. Editoração de revistas científicas. Análise das instruções aos autores de 19 revistas brasileiras. Acta Cir Bras. 1995;10(2):55-60.

12. Dimitri A, Christakis MD, Frederick PR. Publication Ethics: Editors Perspectives. J Pediatric. 2006;149(1 Suppl):S39-42.

13. Amdur RJ, Biddle C. Institutional review board approval and publication of human research results. JAMA. 1997;277(11):909-14.

14. The Nuremberg Code (1947). BMJ. 1996;313(7070):1448.

15. World Medical Association: Declaration of Helsinki. Recommendations guiding physicians in biomedical research involving human subjects. JAMA. 1997;277(11):925-6

16. Zoboli ELCP, Spinetti SR. Comitês de Ética em pesquisa com seres humanos. In: JE Siqueira, Zoboli E, Kipper SJ. Biótica Clínica. São Paulo: Gaia; 2008.
17. Tenório MCM, Bezerra J, Tassitano RM, Barros MVG. Ética na pesquisa com seres humanos: revisão dos artigos publicados na Rev Paulista de Educação Física (1996-2004). Rev Bras Educ Fís Esp. 2005;19(4):329-35.

18. International Committee of Medical Journal Editors (ICMJE). [cited Nov. 20, 2009] Available from: http://www.icmje.org/.

19. Sardenberg T, Müller SS, Pereira HR, Oliveira RA, Hossne WS. Análise dos aspectos éticos da pesquisa em seres humanos contidos nas instruções aos autores de 38 revistas de ortopedia e traumatologia. Acta Ortop Bras. 2002;10(2):15-8.

20. Olson CM, Jobe KM. Reporting approval by research ethics committees and subjects' consent in human resuscitation research. Resuscitation. 1996;31(3):255-63.

21. Rennie D, Yank V. Disclosure to the reader of institutional review board approval and informed consent. JAMA. 1997;277(11):922-3.

22. Matot I, Pizov R, Sprung CL. Evaluation of Institutional Review Board review and informed consent in publications of human research in critical care medicine. Crit Care Med. 1998;26(9):1596-602.

23. Yank V, Rennie D. Reporting of informed consent and ethics committee approval in clinical trials. JAMA. 2002;287(21):2835-8.

24. Weil E, Nelson RM, Ross LF. Are research ethics standards satisfied in pediatric journal publications? Pediatrics. 2002;110(2 Pt 1):364-70.

25. Atlas AMC. Emerging ethical issues in instructions to authors of high impact biomedical journals. J Med Libr Assoc. 2003;91(4):442-9.

26. Myles PS, Tan N. Reporting of ethical approval and informed consent in clinical research published in leading anesthesia journals. Anesthesiology. 2003;99(5):1209-13.

27. Spinetti SR. Análise Ética em Artigos Científicos que Envolvam Seres Humanos, no Período de 1990 - 1996. [Dissertação]. Faculdade de Saúde Pública da Universidade de São Paulo (SP), 2001

28. Pearn I. Publication: an ethical imperative. BMJ. 1995;310(6990):1313-5.

29. Office for Human Research Protections US - Department of Health and Human Services. 2009. International Compilations of Human Research Protection. [cited Nov. 15, 2009] Available from: http://www.hhs.gov/ohrp/ international/HSPCompilation.pdf.

30. Thomson Reuters. [cited Aug. 15, 2009] Available from: <http:// thomsonreuters.com/ $>$.

31. Guimarães AJ. A pesquisa médica e biomédica no Brasil. Comparações com o desempenho científico brasileiro e mundial. Ciênc Saúde Coletiva. 2004;9(2):303-27. 